\title{
Tsunami source of the 2004 off the Kii Peninsula earthquakes inferred from offshore tsunami and coastal tide gauges
}

\author{
Kenji Satake ${ }^{1}$, Toshitaka Baba ${ }^{2}$, Kenji Hirata ${ }^{2}$, Shin-Iti Iwasaki ${ }^{3}$, Teruyuki Kato ${ }^{4}$, Shunichi Koshimura ${ }^{5}$, \\ Jun Takenaka ${ }^{6}$, and Yukihiro Terada ${ }^{7}$ \\ ${ }^{1}$ Active Fault Research Center, National Institute of Advanced Industrial Science and Technology, Tsukuba, Japan \\ ${ }^{2}$ Japan Agency for Marine-Earth Science and Technology, Yokosuka, Japan \\ ${ }^{3}$ National Research Institute for Earth Science and Disaster Prevention, Tsukuba, Japan \\ ${ }^{4}$ Earthquake Research Institute, University of Tokyo, Bunkyo-ku, Tokyo, Japan \\ ${ }^{5}$ Disaster Reduction and Human Renovation Institution, Kobe, Japan \\ ${ }^{6}$ Seismological and Volcanological Department, Japan Meteorological Agency, Tokyo, Japan \\ ${ }^{7}$ Hitachi Zosen Corporation, Taisho-ku, Osaka, Japan
}

(Received November 30, 2004; Revised March 5, 2005; Accepted March 7, 2005)

\begin{abstract}
Tsunamis from the 2004 off the Kii Peninsula earthquakes (M 7.1 and 7.4) were recorded on offshore tsunami gauges, a GPS tsunami gauge and eight bottom-pressure gauges, as well as coastal tide gauges located south of Honshu and Shikoku. The maximum amplitudes on the GPS and bottom-pressure gauges were several to ten $\mathrm{cm}$, while those on tide gauges were up to $0.9 \mathrm{~m}$. We first computed tsunami waveforms from the earthquake source models proposed Yamanaka (2004) and Yagi (2004) from seismic waveform analysis, and compared them with the observed waveforms. For the first event (foreshock), both models produce similar waveforms with the observations. For the second event (mainshock), the waveforms computed from the Yamanaka model is closer to the observed waveforms, but there are still discrepancies between the observed and computed waveforms. We then performed tsunami waveform inversions to estimate the water height distributions in the source area. The foreshock source is $\sim 1600 \mathrm{~km}^{2}$ with the maximum water height of $0.2 \mathrm{~m}$. The estimated tsunami source area for the mainshock, $\sim 3600 \mathrm{~km}^{2}$ with the maximum of $0.6 \mathrm{~m}$, extends $\sim 60 \mathrm{~km}$ toward northwest and $\sim 40 \mathrm{~km}$ southwest from the epicenter along the aftershock distribution, suggesting that multiple faulting was involved in the mainshock.
\end{abstract}

Key words: The 2004 off the Kii Peninsula earthquake, tsunami source, initial water height distribution, tsunami waveform inversion.

\section{Introduction}

Two $M \sim 7$ earthquakes occurred off Kii Peninsula on September 5, 2004. The origin time, hypocenter and magnitude estimated by the Japan Meteorological Agency (JMA) are as follows. The first event: 19:07:7.5 (Japan Standard Time, GMT + 9), $33^{\circ} 1.7^{\prime} \mathrm{N}, 136^{\circ} 48.0^{\prime} \mathrm{E}$, depth 38 $\mathrm{km}$ and $M=7.1$. The second event: $23: 57: 16.9,33^{\circ} 8.6^{\prime} \mathrm{N}$, $137^{\circ} 8.5^{\prime} \mathrm{E}$, depth $44 \mathrm{~km}$ and $M=7.4$. We call the first and second event as foreshock and mainshock, respectively, in this paper. The largest aftershock $(M=6.4)$ occurred at 8:29:36.2 on September 7 , at $33^{\circ} 12.3^{\prime} \mathrm{N}, 137^{\circ} 17.7^{\prime} \mathrm{E}$, depth $41 \mathrm{~km}$.

These earthquakes occurred near the axis of Nankai trough, but the Harvard CMT solutions (Fig. 1) indicate that they were not interplate earthquakes associated with the subduction of the Philippine Sea plate. Seismic body wave analysis (Hara, 2005; Yagi, 2004; Yamanaka, 2004) and the aftershock distribution indicate a complex rupture process.

These earthquakes generated tsunamis. The maximum tsunami height from the foreshock was $0.6 \mathrm{~m}$ at Kozushima,

Copy right(c) The Society of Geomagnetism and Earth, Planetary and Space Sciences (SGEPSS); The Seismological Society of Japan; The Volcanological Society of Japan; The Geodetic Society of Japan; The Japanese Society for Planetary Sciences; TERRAPUB while those of the mainshock were $0.9 \mathrm{~m}$ at Kozushima and Kushimoto. In addition to these coastal tide gauges, the tsunamis were recorded on many offshore tsunami gauges, a GPS tsunami gauge and bottom-pressure gauges, installed south of Honshu and Shikoku.

In this paper, we report the tsunami waveforms recorded on the offshore tsunami and coastal tide gauges, and analyze them to infer the tsunami source. We first describe the tsunami records on an GPS tsunami gauge and eight bottom-pressure gauges. We next compute tsunami waveforms at these gauges from heterogeneous slip distributions proposed by Yamanaka (2004) and Yagi (2004), and compare them with the observed waveforms. Because there are some discrepancies between the observed and computed waveforms, we then perform inversions of tsunami waveforms to estimate the initial water height distribution in the tsunami source area.

\section{Offshore Tsunami and Coastal Tide Gauge Data}

Tsunamis from both the foreshock and the mainshock were recorded on offshore tsunami gauges, a GPS tsunami gauge and eight cabled bottom-pressure gauges, as well as coastal tide gauges (Fig. 1). 


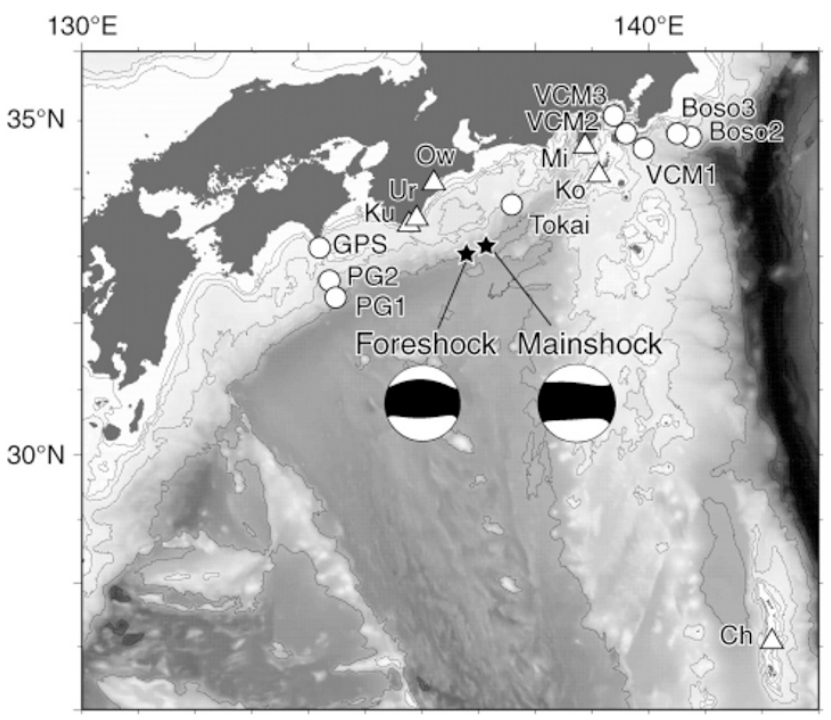

Fig. 1. Location map. The epicenters (stars) and the Harvard CMT solutions (beach balls) of foreshock and mainshock are shown. Offshore tsunami (GPS and bottom-pressure gauges operated by JMA, NIED and JAMSTEC) gauges are shown by circles and coastal gauges are shown by triangles. Coastal gauges $\mathrm{Ku}$ (Kushimoto), Ur (Uragami), Ow (Owase) and Ch (Chichijima) are operated by JMA, while Mi (Minamiizu) and Ko (Kozushima) are by JCG. The tsunami simulation was carried out in the map region using the bathymetry shown (provided by Japan Hydrographic Association).

The GPS tsunami gauge was installed in April 2004 about $13 \mathrm{~km}$ off Cape Muroto, where the water depth is about $100 \mathrm{~m}$. The gauge uses Real-Time Kinematic (RTK) GPS technique to estimate the location and altitude of water surface (Kato et al., 2000). The sampling interval is $1 \mathrm{~s}$ with an accuracy of a few $\mathrm{cm}$. The original data are dominated by high frequency wind waves with amplitudes of about $5 \mathrm{~m}$ (Fig. 2), and the tsunami signal is not easily visible.

Eight bottom-pressure gauges are operated by three different organizations. Two gauges off Cape Muroto, PG1 (water depth about $2308 \mathrm{~m}$ ) and PG2 (1507 m) by Japan Agency for Marine-Earth Science and Technology (JAMSTEC), Tokai (water depth about $2202 \mathrm{~m}$ ), Boso2 $(2098 \mathrm{~m})$ and Boso3 (1912 m) operated by JMA, and VCM1 (2189 m), VCM2 (1848 m) and VCM3 (1266 m) by National Research Institute for Earth Science and Disaster Prevention (NIED). These gauges sample seafloor water pressure at 0.1 to $1 \mathrm{~s}$ intervals and the data are sent through cables. They could detect water height change with an accuracy of $5 \mathrm{~mm}$ by the thermal noise reduction treatments (Iwasaki et al., 1997, Monma et al., 1997, Eguchi et al., 1998). The original records all contain high frequency seismic waves, and except for PG1 and PG2, the tsunami signal is not visible (Fig. 2). The records also contain the ocean tides.

We filter these original records to retrieve the tsunami signal. We first apply time-domain low-pass filter with a width of $2 \mathrm{~min}$ (with cosine-shape lobe) to remove the shorter-period wind and seismic waves. We then approximate the tidal component by fitting a polynomial function of order 5, and remove the tides from the original records. The filtered data clearly show the tsunami signals (Fig. 2).

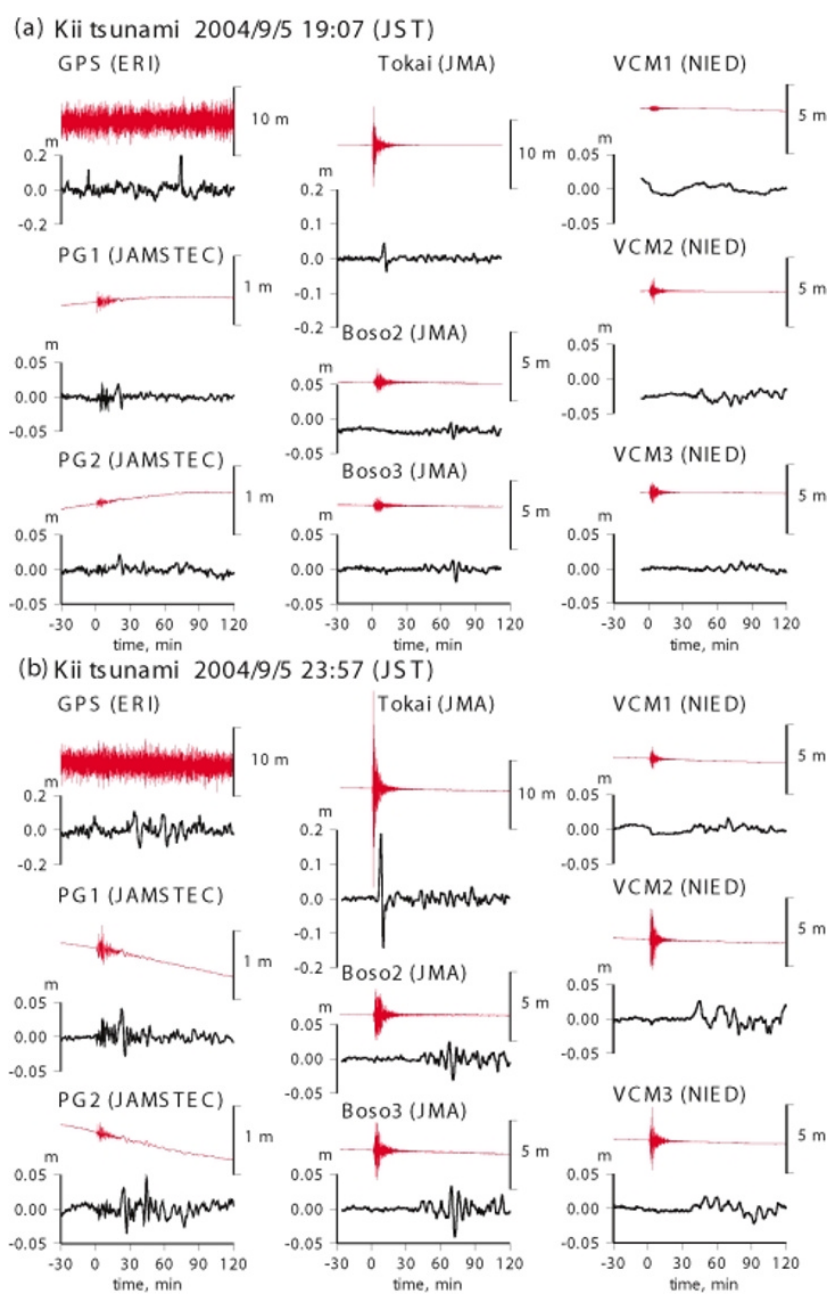

Fig. 2. Tsunamis recorded on offshore tsunami gauges (GPS gauge and bottom-pressure gauges). At each station (the locations are shown in Fig. 1) the upper red traces show the records including the short-period and tidal components with the sampling intervals of $1 \mathrm{~s}$ except for PG1 and PG2 (10 s). The vertical scales for the bottom-pressure gauges show corresponding water heights (in meters) converted assuming the hydrostatic pressure. The bottom black traces are the tsunami signals by filtering out the short-period and tidal components. See text for processing details.

The tsunami signal has a period of a few to ten min with an amplitude of a few to nearly $20 \mathrm{~cm}$ (the maximum amplitude was registered at Tokai station).

Coastal tide gauges also digitally record water heights. We use coastal tide gauges at Kushimoto, Uragami, Owase, Chichijima (operated by JMA), Minamiizu, and Kozushima (operated by Japan Coast Guard, or JCG). The sampling interval is $15 \mathrm{sec}$ for JMA data and $30 \mathrm{sec}$ for JCG data.

\section{Forward Modeling}

Yamanaka (2004) and Yagi (2004) analyzed teleseismic body waves of the foreshock and the mainshock, and estimated the slip distributions. We first compute seafloor deformation from their slip distributions using Okada's (1985) formulas, then compute tsunami waveforms at the offshore and coastal gauges, and compare them with the observed waveforms.

Yamanaka (2004) estimated both slip amount and direction at each subfault location. The foreshock fault strikes 

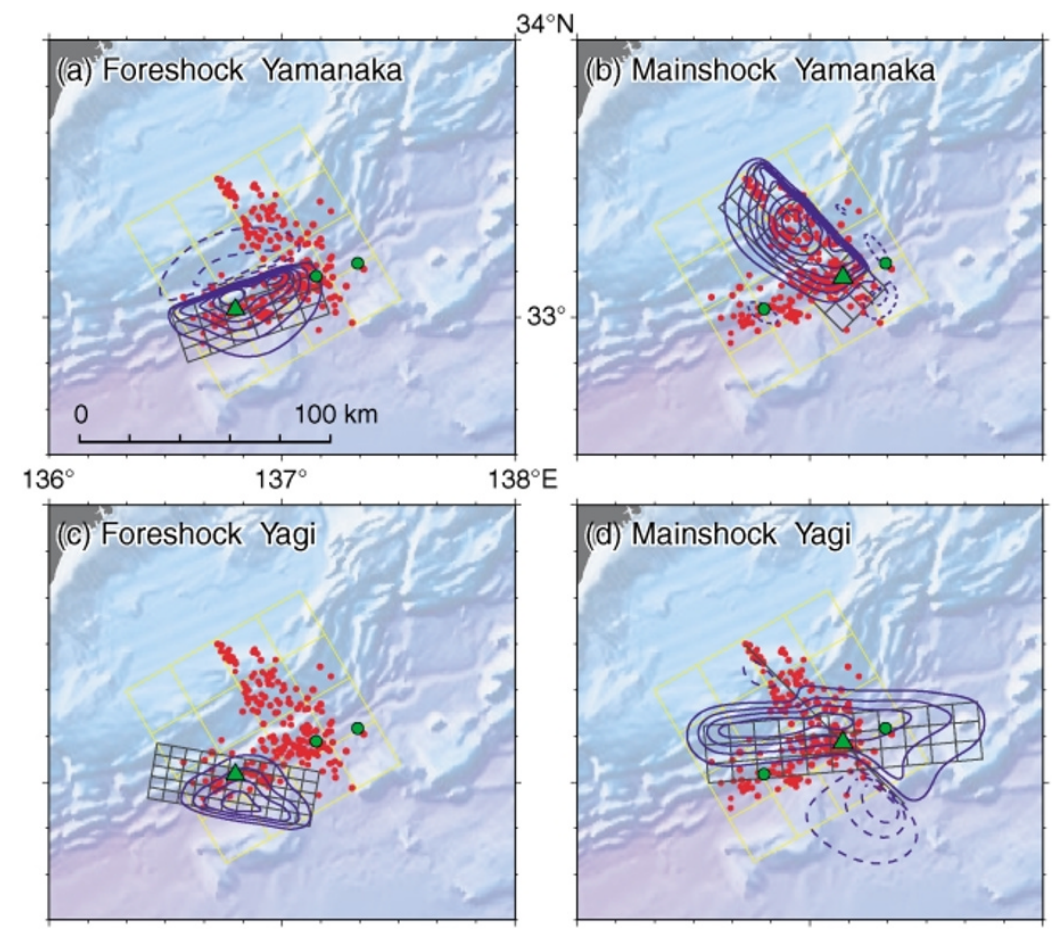

Fig. 3. Ocean bottom deformation computed from heterogeneous slip distribution estimated from seismic wave analyses. (a) Foreshock model of Yamanaka (2004), (b) Mainshock model of Yamanaka (2004), (c) Foreshock model of Yagi (2004) and (d) Mainshock model of Yagi (2004). Projection of subfaults on which the slip distribution was mapped is shown by thin black lines. The green symbols indicate the epicenters of the foreshock, mainshock and the largest aftershock (the triangle is foreshock in (a) and (c) and the mainshock in (b) and (d)). The blue contours indicate the computed bottom deformation, solid curves are for uplift $(0.2 \mathrm{~m}$ interval $)$ and dashed lines are subsidence $(0.1 \mathrm{~m}$ interval $)$. Red dots are aftershocks occurred before 24:00 September 6 and located by JMA. The cells used for the inversion (Fig. 5) are overlaid. The bathymetry data were provided by Japan Hydrographic Association.

(a) 2004 Kii foreshock

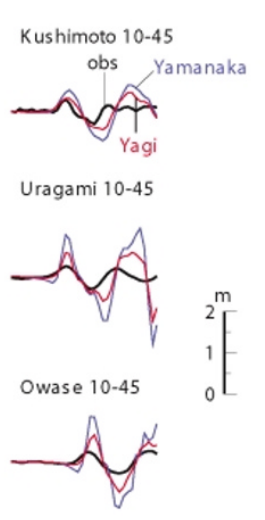

Kozushima $20-70$

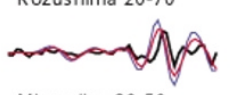

Minamizu 20-50

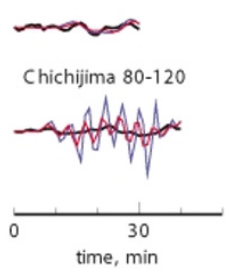

GPS $0-60$

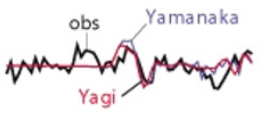

PG $10-60$

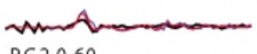

PG2 0-60

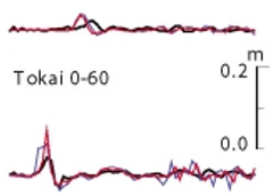

VCM1 20-80

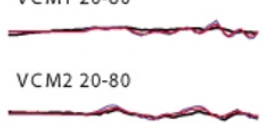

VCM3 20-80

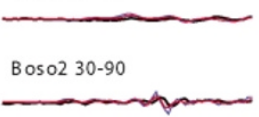

Boso3 30-90

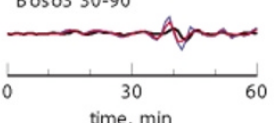

(b) $2004 \mathrm{Kii}$ mainshock

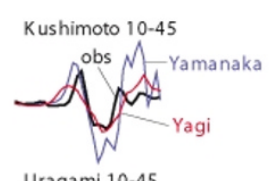

Uragami $10-45$

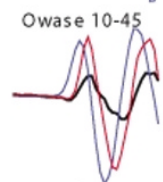

Kozushima 20-70
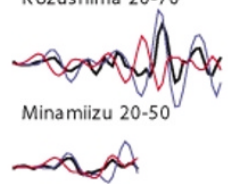

Chichijima 80-120

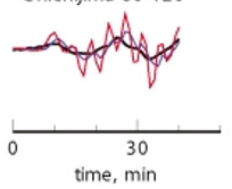

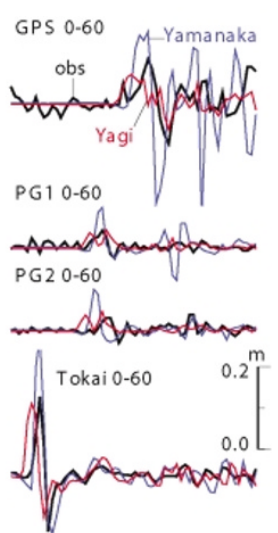

VCM1 20-80
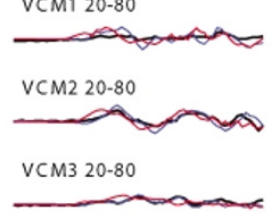

Boso2 30-90

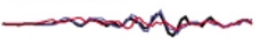

Boso3 30-90

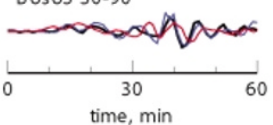

Fig. 4. Comparison of the observed (black) waveforms with those calculated from the source models of Yamanaka (2004) (blue) and Yagi (2004) (red). The left column is for coastal tide gauge stations and right column is for tsunami (GPS and bottom-pressure) gauges. Note the different amplitude scales. Numbers next to the station names indicate the time window (min from the earthquake origin time) of the waveforms. (a) Foreshock, (b) Mainshock. 
ENE-WSW (strike $71^{\circ}$ ) and dips at $56^{\circ}$ toward south. Dipslip is concentrated in an area about $40 \mathrm{~km} \times 20 \mathrm{~km}$, with the maximum slip of $3.9 \mathrm{~m}$. The mainshock occurred on a plane striking NW-SE $\left(135^{\circ}\right)$ and dipping $40^{\circ}$ toward southwest. The slip is nearly pure dip-slip at a deep part of the fault, while there is more right-lateral slip at the shallow part. The slip is distributed in an area about $50 \mathrm{~km} \times 30$ $\mathrm{km}$ with the maximum slip of $6.5 \mathrm{~m}$. The faults and slip distributions roughly coincide with the aftershock distribution. The computed seafloor deformation also extends along the aftershock distribution (Fig. 3). The moment magnitude $\mathrm{Mw}$ is 7.3 for the foreshock, 7.4 for the mainshock, and 6.6 for the largest aftershock.

Yagi (2004) fixed the slip direction on the fault plane and estimated the distribution of the slip amount. He concluded that the foreshock occurred on a plane striking WNW-ESE and dipping toward north (strike $280^{\circ}$, dip $42^{\circ}$, rake $105^{\circ}$ ). His slip area is somewhat smaller than Yamanaka's and the largest maximum slip is $5.1 \mathrm{~m}$. Yagi proposed that the mainshock involves both dip-slip faulting on a plane striking ENE-WSW and dipping southward (strike $85^{\circ}$, dip $40^{\circ}$, rake $90^{\circ}$ ), and right-lateral strike-slip faulting on a vertical plane striking NW-SE (strike $315^{\circ}$, dip $90^{\circ}$, rake $155^{\circ}$ ). The seafloor deformation computed from his slip distribution is somewhat different from Yamanaka's and also from aftershock distribution (Fig. 3).

Tsunami waveforms are computed by assuming linear long-waves. Because the wavelength of seafloor deformation is a few tens of $\mathrm{km}$ (Fig. 3) while the water depth is $<4 \mathrm{~km}$, the long-wave approximation is appropriate. The tsunami amplitude is $<1 \mathrm{~m}$, hence the linearity assumption is also appropriate. The finite-difference method is adopted for the computations. The grid size is $30 \mathrm{sec}$ of the arc (about $900 \mathrm{~m}$ along the meridian), but finer grid (6 sec or $180 \mathrm{~m}$ along the meridian) is adopted near the coastal tide gauge stations. The bathymetry grid was made from digital bathymetric data compiled by Japan Hydrographic Association. The time step for the computation is $1 \mathrm{~s}$, and $2 \mathrm{hrs}$ of tsunami propagation is computed in the domain shown in Fig. 1. The details of tsunami numerical computation are described in Satake (2002).

The tsunami waveforms computed from the two models of the foreshock are compared with the observation in Fig. 4(a). The computed waveforms from the models of Yamanaka (2004) and Yagi (2004) are similar each other, and also similar to the observations. This is not surprising, because the computed initial water height distribution in the source region is similar (Fig. 3(a) and (c)), although their faults dip in opposite directions (south and north, respectively). At nearby coastal tide gauges located northwest of the source (Uragami and Owase), the Yamanaka model produces negative initial motion followed by large positive pulse, which is not consistent with the observation (Fig. 4(a)). Although the difference is not significant, the northward dipping source proposed by Yagi (2004) is preferred.

The two models show larger differences for the mainshock (Fig. 4(b)). At most of the stations, the waveforms computed from the Yamanaka model produce larger amplitudes than Yagi's. The phases are also different. At the northwestern coastal stations (Kushimoto, Uragami and Owase), the computed tsunami arrivals from both models are earlier than the observations. At the eastern stations (Tokai, Kozushima, Minamiizu), the computed arrivals from the Yagi model is earlier while the Yamanaka model is similar to the observed. Although there is still some discrepancies between the observed and computed waveforms, Yamanaka model seems to better reproduce the observations. In particular, the observed and computed waveforms are very similar at offshore VCM2, VCM3 and Boso 2 and Boso 3 stations.

\section{Waveform Inversion for Initial Water Height Distributions}

We estimate the water surface height (uplift or subsidence) from the tsunami data alone. Because the earthquake series is complex, it is not obvious which fault plane(s) was involved in the foreshock and mainshock processes. We divide the possible tsunami source area into 16 cells (the cell interval is $20 \mathrm{~km}$ ) and estimate the average water height from the tsunami waveforms. It is similar but slightly different from the tsunami waveform inversion technique developed by Satake (1987); we do not assume any fault plane and invert for the water height distribution. Such a waveform inversion for water height was first attempted by Aida (1972). Baba et al. (2005) also made similar inversion by using smaller cell size hence with higher resolution, but they used less than a half of the available offshore tsunami gauge data with more limited azimuthal distribution. Baba et al. (2005) only analyzed the mainshock. Matsumoto and Mikada (2005) also analyzed the JAMASTEC's bottom-pressure gauge data to estimate the fault geometry of both foreshock and mainshock.

The 16 cells are placed along the $\mathrm{N} 60^{\circ} \mathrm{E}$ and $\mathrm{N} 30^{\circ} \mathrm{W}$ directions. In each cell, a uniform uplift of $1 \mathrm{~m}$ is assumed in the central part with the surrounding linear slopes. More specifically, each cell is a pyramid shape with a flat top, and the bottom is a $30 \mathrm{~km}$ square while the top is a $10 \mathrm{~km}$ square. The interval of the cell center is $20 \mathrm{~km}$. This interval was chosen by considering the spatial resolution of our inversion, which is estimated from the temporal resolution of tsunami signal. The temporal resolution of tsunami signal is $2 \mathrm{~min}$, because we have filtered out the shorter period component. The corresponding spatial resolution at the tsunami source is 17 to $24 \mathrm{~km}$, because the ocean depth around the tsunami source is 2000 to $4000 \mathrm{~m}$ where the tsunami velocity is $140-200 \mathrm{~m} / \mathrm{s}$. The relative size of cells to the water depth also satisfies the long-wave assumption.

A checker-board test confirmed that our inversion is wellposed. A numerical test of inversion was performed for synthetic waveforms computed from an alternate uplift $(+1 \mathrm{~m})$ and subsidence $(-1 \mathrm{~m})$ pattern, commonly used to test the resolution in seismic tomography (e.g., Shearer, 1999, p. 80). This inversion test completely reconstructed the initial water height distribution. Hence the neighboring positive and negative heights in the solution would be a real feature.

The waveform inversion is performed for tsunami waveforms recorded at six coastal tide gauges and nine offshore tsunami (a GPS gauge and eight bottom-pressure) gauges 


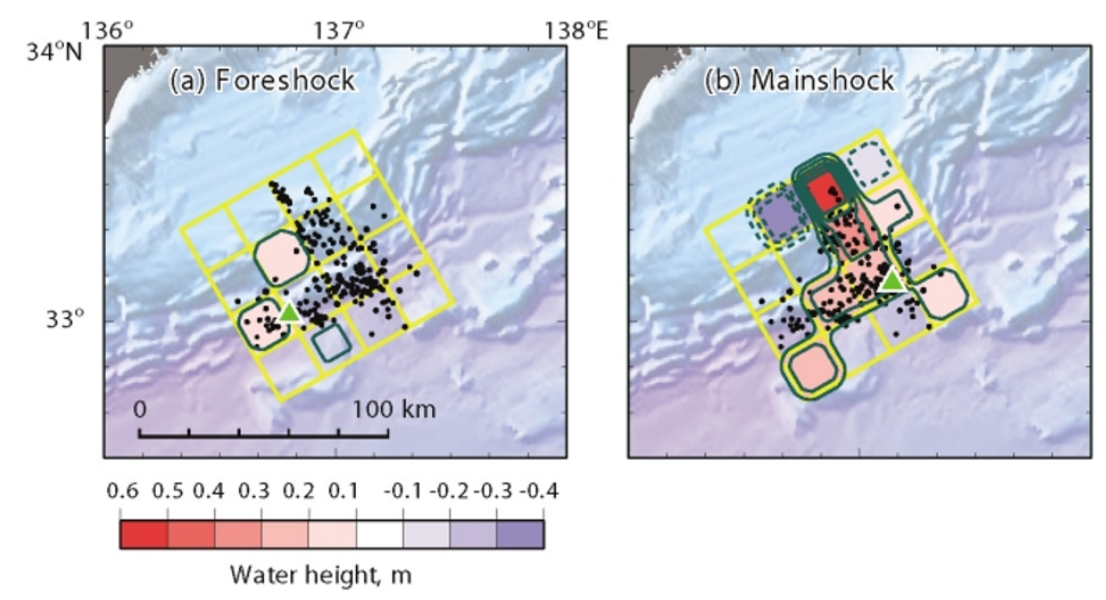

Fig. 5. The water height distribution of the foreshock (left) and mainshock (right) estimated by inversion of tsunami waveforms. Red and blue colors indicate uplift and subsidence, respectively, on the 16 cells. The contour interval is $0.1 \mathrm{~m}$. The green triangles are the epicenters of the foreshock and mainshock. The black dots are aftershocks of the foreshock and mainshock within 24 hours (by 24:00 September 6) located by JMA. The background bathymetry was provided by Japan Hydrographic Association.

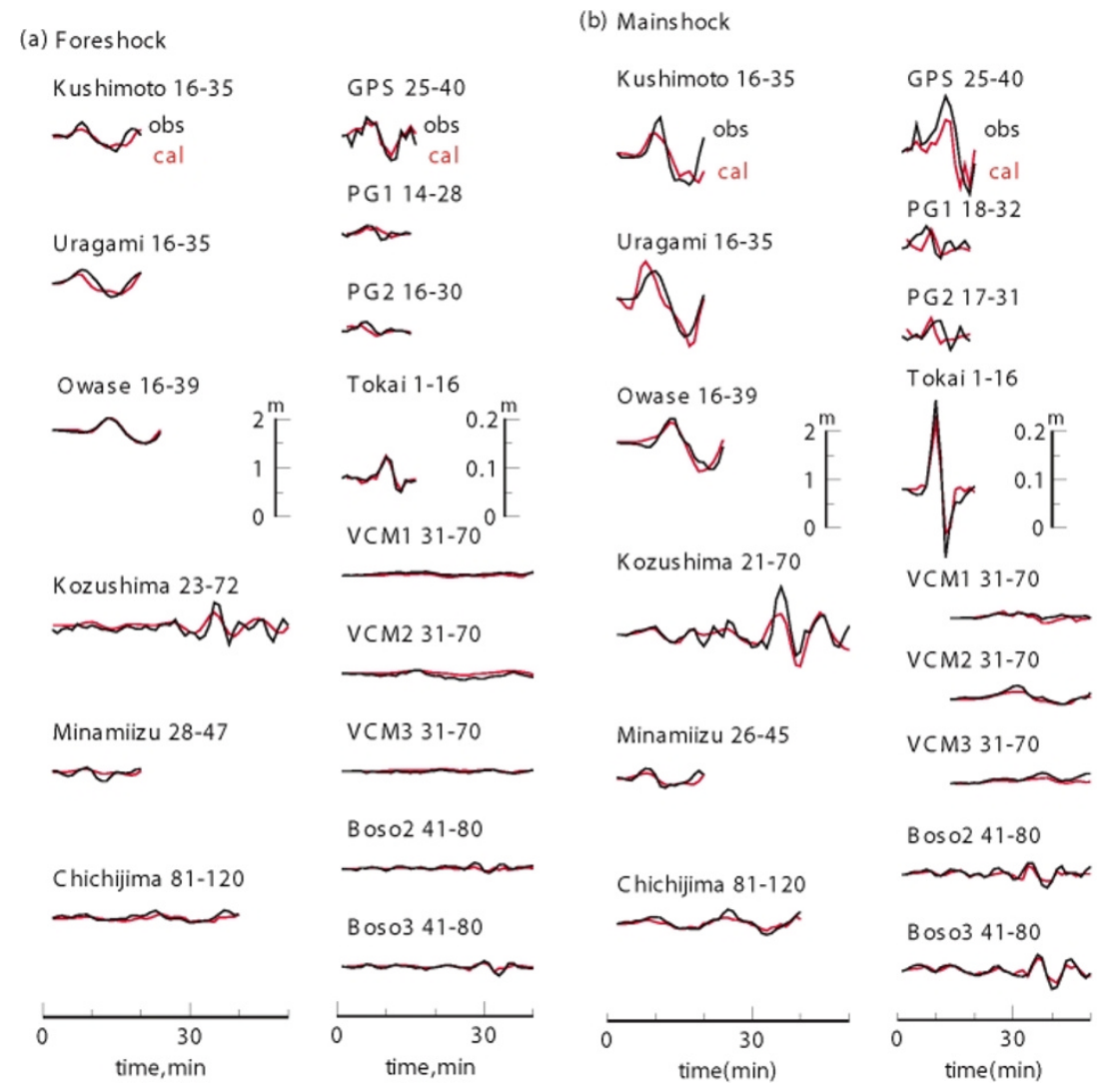

Fig. 6. Comparison of the observed (black) and calculated (red) waveforms for the foreshock. The left column is for coastal tide gauge stations and right column is for tsunami (GPS and bottom-pressure) gauges. Note the different amplitude scales. Numbers next to the station names indicate the time window (min from the earthquake origin time) of the waveforms. (a) Foreshock, (b) Mainshock.

for both the foreshock and the mainshock. The tsunami amplitudes are larger on coastal tide gauges because of tsunami shoaling. For the mainshock, the maximum and the RMS amplitudes of the coastal tide gauge records are $0.99 \mathrm{~m}$ and $0.27 \mathrm{~m}$ for the tide gauge records, while they are $0.18 \mathrm{~m}$ and $0.025 \mathrm{~m}$ for the offshore tsunami gauges. We therefore weight them as 1:10 in the inversion. The effect of varying the weight will be discussed with the results. The observed data resampled at $1 \mathrm{~min}$ interval are used and the total data point is 436 from the 15 gauges.

The associated errors for the water height are estimated by delete-half jackknife method, a resampling technique in which the inversion is repeated 100 times by randomly deleting a half of the data (waveforms) to estimate the standard errors (e.g., Tichlaar and Ruff, 1989). Only cells with water height (uplift or subsidence) larger (in absolute sense) than either the error amount or $0.1 \mathrm{~m}$ are considered as a part of the tsunami source. 


\section{Tsunami Source}

The foreshock source extends over three cells around the epicenter. In those cells, a small amount of uplift (up to $0.2 \mathrm{~m}$ ) is estimated (Fig. 5(a)). The tsunami source area and uplifted water volume is computed as $1600 \mathrm{~km}^{2}$ and $2 \times 10^{8} \mathrm{~m}^{3}$, respectively. The uplifted area roughly coincides with the uplifted area computed from the slip distribution of Yagi (2004) (Fig. 3(c)), although the uplift amount is smaller.

The mainshock source shows a more complex pattern. The source extends nine cells (Fig. 5(b)). The tsunami source area and uplifted water volume is computed as 3600 $\mathrm{km}^{2}$ and $1 \times 10^{9} \mathrm{~m}^{3}$, respectively. The large uplift area extends toward northwest and southwest from the epicenter, and roughly coincides with the aftershock distribution. The northwestward slip matches with the result of Yamanaka (2004), but the southwestward slip along the aftershock distribution is also recognized. The largest uplift $(0.6 \mathrm{~m})$ is estimated on the northwestern edge, about $60 \mathrm{~km}$ from the epicenter, and accompanied by subsidence $(-0.4 \mathrm{~m})$ on the southwest side. The uplift area also extends $\sim 40 \mathrm{~km}$ toward southwest. These features are very stable; when we change the relative weight of inversion between the offshore tsunami data and the coastal tide gauge data, the result does not change. However, a small subsidence on the northeast corner and a small uplift at the southeast and southwest corners are less stable. The amount of displacement on these three corner cells becomes similar to the error amount when we change the relative weight. The uplift at the southwestern corner, for example, is constrained by only coastal tide gauge data; the displacement becomes zero if we use only offshore tsunami gauge data.

Both forward and inverse modelings indicate that the mainshock was not a simple faulting, but multiple faulting, in NW-SW and NE-SW directions parallel to the aftershock distribution, were involved. Baba et al. (2005) obtained similar results from more limited azimuthal coverage yet higher resolution.

Tsunami waveforms computed from the estimated water height distribution well reproduce the observed waveforms (Fig. 6). The maximum amplitudes of the observed tsunamis (after the tidal component is removed) were $0.5 \mathrm{~m}$ and $1.0 \mathrm{~m}$ for the foreshock and mainshock, both registered at Kozushima. The synthetic waveforms do not reproduce these maximum amplitudes, but the waveforms, particularly for the first cycle, are well reproduced.

\section{Conclusions}

The tsunamis from the 2004 off the Kii Peninsula earthquakes were recorded on nine offshore tsunami gauges, as well as coastal tide gauges. Forward computations from source models of Yamanaka (2004) and Yagi (2004) indicate that there are some discrepancies between the observed and computed tsunami waveforms. The water height distribution at the tsunami source was estimated by inversion of tsunami waveforms recorded at offshore tsunami gauges as well as coastal tide gauges. The tsunami source of the mainshock extends both northwest and southwest directions from the epicenter and roughly coincides with the aftershock distribution. The complex water height distribution suggests that more than one faulting may be contributed for seismic wave and tsunami generation from the mainshock.

Acknowledgments. The authors' responsibilities are as follows. System maintenance, quality control and processing for JAMSTEC data: TB and KH, NIED data: IS, GPS data: TK, SK and YT, and JMA data: JT, forward and inverse computations of tsunami: KS and SK, manuscript preparation : KS. Coastal tide gauge records were provided by Japan Meteorological Agency and Japan Coast Guard. We used bathymetry data compiled and provided by Japan Hydrographic Association. Drs. Y. Yagi and Y. Yamanaka provided us their source models (slip distribution). Eric Geist and an anonymous reviewer provided constructive comments to improve the paper.

\section{References}

Aida, I. Numerical estimation of a tsunami source, Zisin (J. Seism. Soc. Jpn) ser 2, 25, 343-352, 1972.

Baba, T., P. R. Cummins, and T. Hori, Compound fault rupture during the 2004 off the Kii Peninsula earthquake ( $M$ 7.4) inferred from highly resolved coseismic sea-surface deformation, Earth Planets Space, 57, this issue, 167-172, 2005.

Eguchi, T., Y. Fujinawa, E. Fujita, S. I. Iwasaki, I. Watabe, and H. Fujiwara, A real-time observation network of ocean-bottom-seismometers deployed at the Sagami trough subduction zone, central Japan, Marine Geophys. Res., 20, 73-94, 1998.

Hara, T., Change of the source mechanism of the main shock of the 2004 off the Kii peninsula earthquakes inferred from long period body wave data, Earth Planets Space, 57, this issue, 179-183, 2005.

Iwasaki, S. I., T. Eguchi, Y. Fujinawa, E. Fujita, I. Watabe, E. Fukuyama, H. Fujiwara, and K. Hishiki, Precise tsunami observation system in the deep ocean by an ocean bottom cable network for the prediction of earthquakes and tsunamis, in Perspectives on Tsunami Hazard Reduction, edited by G. Hebenstreit, 47-66, Kluwer Academic Pub., 1997.

Kato, T., Y. Terada, M. Kinoshita, H. Kakimoto, H. Isshiki, M. Matsuishi, A. Yokoyama, and T. Tanno, Real-time observation tsunami by RTKGPS, Earth Planets Space, 52, 841-845, 2000.

Matsumoto, H. and H. Mikada, Fault geometry of the 2004 off the Kii peninsula earthquake inferred from offshore pressure waveforms, Earth Planets Space, 57, this issue, 161-166, 2005.

Monma, H., N. Fujiwara, R. Iwase, K. Kawaguchi, S. Suzuki, and H. Kinoshita, Monitoring system for submarine earthquakes and deep sea environment, Proc. MTS/IEEE OCEANS '97, 2, 1453-1459, 1997.

Okada, Y., Surface deformation de to shear and tensile faults in a halfspace, Bull. Seism. Soc. Am., 75, 1135-1154, 1985.

Satake, K., Inversion of tsunami waveforms for the estimation of a fault heterogeneity: method and numerical experiments, J. Phys. Earth, 35, 241-254, 1987.

Satake, K., Tsunamis, in International Handbook of Earthquake and Engineering Seismology, 81A, edited by W. H. K. Lee, H. Kanamori, P. C. Jennings, and C. Kisslinger, 437-451, 2002.

Shearer, P. M., Introduction to seismology, Cambridge Univ. Press, 260 pp.

Tichelaar, B. W. and L. J. Ruff, How good are our best models? Jackknifing, Bootstrapping, and earthquake depth, Eos Trans. AGU, 70, 593 and 605-606, 1989.

Yagi, Y., Source model of the Off Kii-Peninsula earthquake, http://iisee. kenken.go.jp/staff/yagi/eq/Japan20040905/Japan20040905_1.html, 2004

Yamanaka, Y., Source process of the 2004 Off Kii-Peninsula earthquakes determined from teleseismic body waves, http://www.eri.u-tokyo.ac.jp/ sanchu/Seismo_Note/2004/EIC153.html, 2004.

K. Satake (e-mail: kenji.satake@aist.go.jp), T. Baba, K. Hirata, S. Iwasaki, T. Kato, S. Koshimura, J. Takenaka, and Y. Terada 